\title{
Bacillus korlensis sp. nov., a moderately halotolerant bacterium isolated from a sand soil sample in China
}

\author{
Lei Zhang, Yang Wang, Jun Dai, Yali Tang, Qiao Yang, Xuesong Luo \\ and Chengxiang Fang
}

Correspondence

Chengxiang Fang

College of Life Sciences, Wuhan University, Wuhan 430072, PR China

\begin{abstract}
A Gram-positive-staining, rod-shaped, motile, spore-forming and moderately halotolerant bacterium, designated ZLC- $26^{\top}$, was isolated from a sand soil sample collected from Xinjiang Province, China, and was characterized by using a polyphasic taxonomic approach. This isolate grew optimally at $30-37{ }^{\circ} \mathrm{C}$ and $\mathrm{pH} 7-8$. It grew with $0-8 \% \mathrm{NaCl}$ (optimum, $0-2 \%$ ). Comparative $16 \mathrm{~S}$ rRNA gene sequence analysis showed that strain $\mathrm{ZLC}-26^{\top}$ was closely related to members of the genus Bacillus, exhibiting the highest $16 \mathrm{~S}$ rRNA gene sequence similarities to Bacillus nealsonii DSM $15077^{\top}$ (97.1\%), B. shackletonii LMG $18435^{\top}(97.0 \%)$, B. siralis $171544^{\top}(97.0 \%)$, B. circulans IAM $12462^{\top}(96.7 \%)$ and B. pocheonensis Gsoil $420^{\top}(96.7 \%)$. Strain ZLC- $26^{\top}$ contained MK-7 as the predominant menaquinone. The diagnostic diamino acid in the cell-wall peptidoglycan was meso-diaminopimelic acid. The major cellular fatty acids were iso$\mathrm{C}_{15: 0}, \mathrm{C}_{16: 1} \omega 11 \mathrm{c}$ and anteiso- $\mathrm{C}_{15: 0}$. The DNA G+C content was $38.2 \mathrm{~mol} \%$. These chemotaxonomic results supported the affiliation of strain $\mathrm{ZLC}-26^{\top}$ to the genus Bacillus. However, low DNA-DNA relatedness values and distinguishing phenotypic characteristics allowed genotypic and phenotypic differentiation of strain $\mathrm{ZLC}-26^{\top}$ from recognized Bacillus species. On the basis of the evidence presented, strain $Z \mathrm{LC}-26^{\top}$ is considered to represent a novel species of the genus Bacillus, for which the name Bacillus korlensis sp. nov. is proposed. The type strain is ZLC- $26^{\top}\left(=\right.$ CCTCC AB $207172^{\top}=$ NRRL B-51302 $\left.{ }^{\top}\right)$.
\end{abstract}

Since the genus Bacillus was first described by Cohn in 1872, the number of Bacillus species has fluctuated widely. Currently, many species originally described as Bacillus have been transferred to related genera. Nevertheless, the genus Bacillus is still considered to be one of the largest genera and currently includes more than 200 species (Euzéby, 2008). Novel Bacillus species from diverse habitats have been described recently (Aino et al., 2008; Albuquerque et al., 2008; Kuisiene et al., 2008). During the course of an investigation of the culturable bacterial community in soil from a sand dune area in Xinjiang Province, China, a large number of bacteria were isolated. In this study, we report on the taxonomic characterization of one of these isolates, designated strain ZLC- $26^{\mathrm{T}}$. On the basis of phenotypic characteristics, chemotaxonomic data,

The GenBank/EMBL/DDBJ accession number for the $16 \mathrm{~S}$ rRNA gene sequence of strain ZLC-26 ${ }^{\top}$ is EU603328.

Maximum-parsimony and maximum-likelihood trees based on 16S rRNA gene sequences showing the phylogenetic relationship of strain ZLC$26^{\top}$ with related taxa are available as supplementary material with the online version of this paper. phylogenetic analysis and DNA-DNA hybridization, the isolate represents a novel species of the genus Bacillus.

Strain ZLC-26 ${ }^{\mathrm{T}}$ was isolated from a sand soil sample collected from Xinjiang Province, China. The soil sample was thoroughly suspended in sterilized water and serial dilutions of the suspension were spread on marine agar 2216 (MA; Difco). Isolation was achieved after incubation at $30{ }^{\circ} \mathrm{C}$ for 1 week. The isolate $\mathrm{ZLC}-26^{\mathrm{T}}$ was routinely cultivated on the same medium at $30{ }^{\circ} \mathrm{C}$ and maintained as a glycerol suspension $(20 \%, \mathrm{v} / \mathrm{v})$ at $-80{ }^{\circ} \mathrm{C}$. The type strains of seven Bacillus species were used as reference strains; Bacillus nealsonii DSM $15077^{\mathrm{T}}$, B. shackletonii DSM $18868^{\mathrm{T}}$, B. siralis DSM $13140^{\mathrm{T}}$, B. pocheonensis DSM $18135^{\mathrm{T}}$ and $B$. benzoevorans DSM $5391^{\mathrm{T}}$ were obtained from the DSMZ, and B. circulans IAM $12462^{\mathrm{T}}$ and $B$. firmus IAM $12464^{\mathrm{T}}$ were obtained from the China Center for Type Culture Collection (CCTCC), China.

Cell morphology, size and motility were examined by using phase-contrast microscopy (BX51 microscope; Olympus). The Gram reaction was carried out according to the classic Gram procedure described by Doetsch (1981). Flagella were observed from silver-nitrate-stained cells of strain 
ZLC- $26^{\mathrm{T}}$ that were incubated on MA slants at $30{ }^{\circ} \mathrm{C}$ for $12 \mathrm{~h}$ (Rhodes, 1958). Growth at different temperatures (4, $7,10,17,25,30,37,42,45$ and $50{ }^{\circ} \mathrm{C}$ ) was investigated on MA for up to 1 week. Growth at various $\mathrm{NaCl}$ concentrations $(0-10 \%, \mathrm{w} / \mathrm{v}$, with increments of $1 \%)$ was investigated in trypticase soy broth (Difco) prepared according to the formula except that $\mathrm{NaCl}$ was excluded. The $\mathrm{pH}$ range for growth was determined in marine broth 2216 (MB; Difco) at $\mathrm{pH} 4.0-11.0$, by using the following buffer system: $\mathrm{pH}$ 4.0-5.0, $0.1 \mathrm{M}$ citric acid/0.1 M sodium citrate; pH 6.0-8.0, 0.1 M K K ${ }_{2} \mathrm{PO}_{4} / 0.1 \mathrm{M} \mathrm{NaOH}$; pH 9.0-10.0, $0.1 \mathrm{M} \quad \mathrm{NaHCO}_{3} / 0.1 \mathrm{M} \quad \mathrm{Na}_{2} \mathrm{CO}_{3} ; \quad$ pH $11.0, \quad 0.05 \mathrm{M}$ $\mathrm{Na}_{2} \mathrm{HPO}_{4} / 0.1 \mathrm{M} \mathrm{NaOH}$. Growth under anaerobic conditions was determined after incubation in an anaerobic chamber (AnaeroJar; Oxoid) for 1 week on MA at $30{ }^{\circ} \mathrm{C}$. Oxidase activity was determined using a $1 \%$ solution of tetramethyl $p$-phenylenediamine (Kovács, 1956). Catalase activity was detected by assessing the production of bubbles after the addition of a drop of $3 \% \mathrm{H}_{2} \mathrm{O}_{2}$. Hydrolysis of starch and casein was tested as described by Smibert \& Krieg (1994) on MA. Tests were also made for hydrolysis of CM-cellulose $(0.1 \%, \mathrm{w} / \mathrm{v})$, chitin from crab shells $(1 \%$, $\mathrm{w} / \mathrm{v})$ and tyrosine $(0.5 \%, \mathrm{w} / \mathrm{v})$. Activities of constitutive enzymes and other physiological properties were determined by using the API 20E, API 20NE, API $50 \mathrm{CH}$ (with API $50 \mathrm{CHB} / \mathrm{E}$ medium) and API ZYM strips (bioMérieux) according to the manufacturer's instructions. Antimicrobial susceptibility testing was performed by the agardiffusion method using antibiotic-impregnated discs (Oxoid) as described by Buczolits et al. (2002).

For 16S rRNA gene sequencing and phylogenetic analysis, DNA was extracted using a commercial genomic DNA extraction kit (ChaoShi-Bio; China). The primer pair 27f $\left(5^{\prime}\right.$-GAGTTTGATCCTGGCTCAG-3') and 1527r (5'AGAAAGGAGGTGATCCAGCC-3') was used for amplification of the 16S rRNA gene (Lane, 1991). PCR and 16S rRNA gene sequencing were carried out as described by Lin et al. (2004). The identification of phylogenetic neighbours and the calculation of pairwise 16S rRNA gene sequence similarities were achieved using the EzTaxon server (http:// www.eztaxon.org/; Chun et al., 2007). Phylogenetic analysis was performed by using MEGA version 3.1 (Kumar et al., 2004) after multiple alignment of the data via ClUSTALX (Thompson et al., 1997). A distance matrix method (distance options according to the Kimura twoparameter model), including clustering by neighbourjoining, and a discrete character-based maximum-parsimony method were used. The relationships among taxa were also established with the maximum-likelihood algorithm in the PHYLIP 3.66 package (Felsenstein, 2006). In each case, bootstrap values were calculated based on 1000 replications.

For DNA-DNA hybridization experiments and determination of the DNA G $+C$ content, genomic DNA of strain ZLC- $26^{\mathrm{T}}$ and four reference strains was prepared according to a modification of the procedure of Wilson (1987). The DNA G + C content of strain ZLC- $26^{\mathrm{T}}$ was determined by
HPLC (UltiMate 3000; Dionex) according to the method of Mesbah et al. (1989). DNA-DNA hybridization was performed fluorometrically by the method of Ezaki et al. (1989), using photobiotin-labelled DNA probes and microdilution wells. Hybridization was performed with five replications for each sample. The highest and lowest values obtained for each sample were excluded and the means of the remaining three values were quoted as DNA-DNA relatedness values. The respiratory quinone system was extracted and determined by HPLC as described by Xie \& Yokota (2003). The isomer type of diaminopimelic acid in the peptidoglycan was determined by using the method described by Staneck \& Roberts (1974). For the determination of the cellular fatty acid methyl ester content, strain ZLC- $26^{\mathrm{T}}$ and five of the reference strains (except $B$. pocheonensis DSM $18135^{\mathrm{T}}$ and $B$. benzoevorans DSM $5391^{\mathrm{T}}$ ) were grown on trypticase soy agar (TSA; Difco) at $30{ }^{\circ} \mathrm{C}$ for $24 \mathrm{~h}$. Because of poor growth on this medium, $B$. pocheonensis DSM $18135^{\mathrm{T}}$ was grown on R2A agar (Difco) and B. benzoevorans DSM $5391^{\mathrm{T}}$ was grown on nutrient agar (NA; Difco) supplemented with $0.4 \%$ yeast extract and $0.2 \%$ benzoate. Fatty acid methyl ester analysis was carried out according to the standard protocol of the Sherlock Microbial Identification System (MIDI, 1999).

Strain ZLC- $26^{\mathrm{T}}$ formed cream-yellow, circular, slightly raised colonies when grown on MA at $30{ }^{\circ} \mathrm{C}$ for 2 days. Cells were Gram-positive-straining, rod-shaped, sporeforming, strictly aerobic and motile by means of peritrichous flagella. Spores were mainly oval and lie in subterminal (occasionally paracentral) positions in slightly swollen sporangia. Other phenotypic features of strain ZLC- $26^{\mathrm{T}}$ are summarized in the species description and a comparison of selective characteristics with closely related type strains is given in Table 1.

For strain ZLC-26 ${ }^{\mathrm{T}}, 1471 \mathrm{bp}$ of the $16 \mathrm{~S}$ rRNA gene sequence was determined. Comparative 16S rRNA gene sequence analysis showed that strain ZLC- $26^{\mathrm{T}}$ was most closely related to members of the genus Bacillus. Strain ZLC- $26^{\mathrm{T}}$ exhibited the highest $16 \mathrm{~S}$ rRNA gene sequence similarities to $B$. nealsonii DSM $15077^{\mathrm{T}}(97.1 \%), B$. shackletonii LMG $18435^{\mathrm{T}}(97.0 \%)$, B. siralis $171544^{\mathrm{T}}$ $(97.0 \%)$, B. circulans IAM $12462^{\mathrm{T}}(96.7 \%)$, B. pocheonensis Gsoil $420^{\mathrm{T}}(96.7 \%), \quad$ B. acidicola $105-2^{\mathrm{T}}(96.6 \%), \quad B$. isabeliae CVS- $8^{\mathrm{T}}(96.5 \%), \quad B$. firmus IAM $12464^{\mathrm{T}}$ $(96.5 \%)$ and B. benzoevorans DSM $5391^{\mathrm{T}}(96.5 \%)$. The 16S rRNA gene sequence similarities to the type strains of all other Bacillus species with validly published names were below $96.4 \%$. In the phylogenetic tree based on the neighbour-joining algorithm (Fig. 1), strain ZLC-26 $6^{\mathrm{T}}$ fell within a coherent cluster comprising $B$. nealsonii DSM $15077^{\mathrm{T}}, B$. siralis $171544^{\mathrm{T}}$, B. circulans IAM $12462^{\mathrm{T}}, B$. benzoevorans DSM $5391^{\mathrm{T}}$ and B. firmus IAM $12464^{\mathrm{T}}$. The topologies of the phylogenetic trees generated using the maximum-parsimony and maximum-likelihood algorithms (Supplementary Figs S1 and S2, available in IJSEM Online) were somewhat different from that of the tree constructed using the neighbour-joining method. 
Table 1. Differential phenotypic characteristics of strain $Z \mathrm{LC}-26^{\top}$ and some related Bacillus species

Strains: 1, Bacillus korlensis sp. nov. ZLC-26 ${ }^{\mathrm{T}}$ (data from this study); 2, B. nealsonii DSM $15077^{\mathrm{T}}$ (Venkateswaran et al., 2003); 3, B. shackletonii DSM $18868^{\mathrm{T}}$ (Logan et al., 2004; Albuquerque et al., 2008); 4, B. siralis DSM 13140 ${ }^{\mathrm{T}}$ (Pettersson et al., 2000); 5, B. circulans IAM 12462 ${ }^{\mathrm{T}}$ (Claus \& Berkeley, 1986; Pettersson et al., 2000); 6, B. pocheonensis DSM 18135 ${ }^{\mathrm{T}}$ (Ten et al., 2007); 7, B. firmus IAM 12464 ${ }^{\mathrm{T}}$ (Claus \& Berkeley, 1986; Pettersson et al., 2000); 8, B. benzoevorans DSM 5391 ${ }^{\mathrm{T}}$ (Pichinoty et al., 1984; Pettersson et al., 2000); 9, B. acidicola 105-2 ${ }^{\mathrm{T}}$ (Albert et al., 2005; Albuquerque et al., 2008); 10, B. isabeliae CVS- $8^{\mathrm{T}}$ (Albuquerque et al., 2008). For acid production, data for columns $1-8$ are from this study and for columns 9-10 from Albuquerque et al. (2008), all with API 50 CH strips. O, Oval; E, ellipsoidal; +, positive; -, negative; (+), weakly positive; v, variable; ND, no data available.

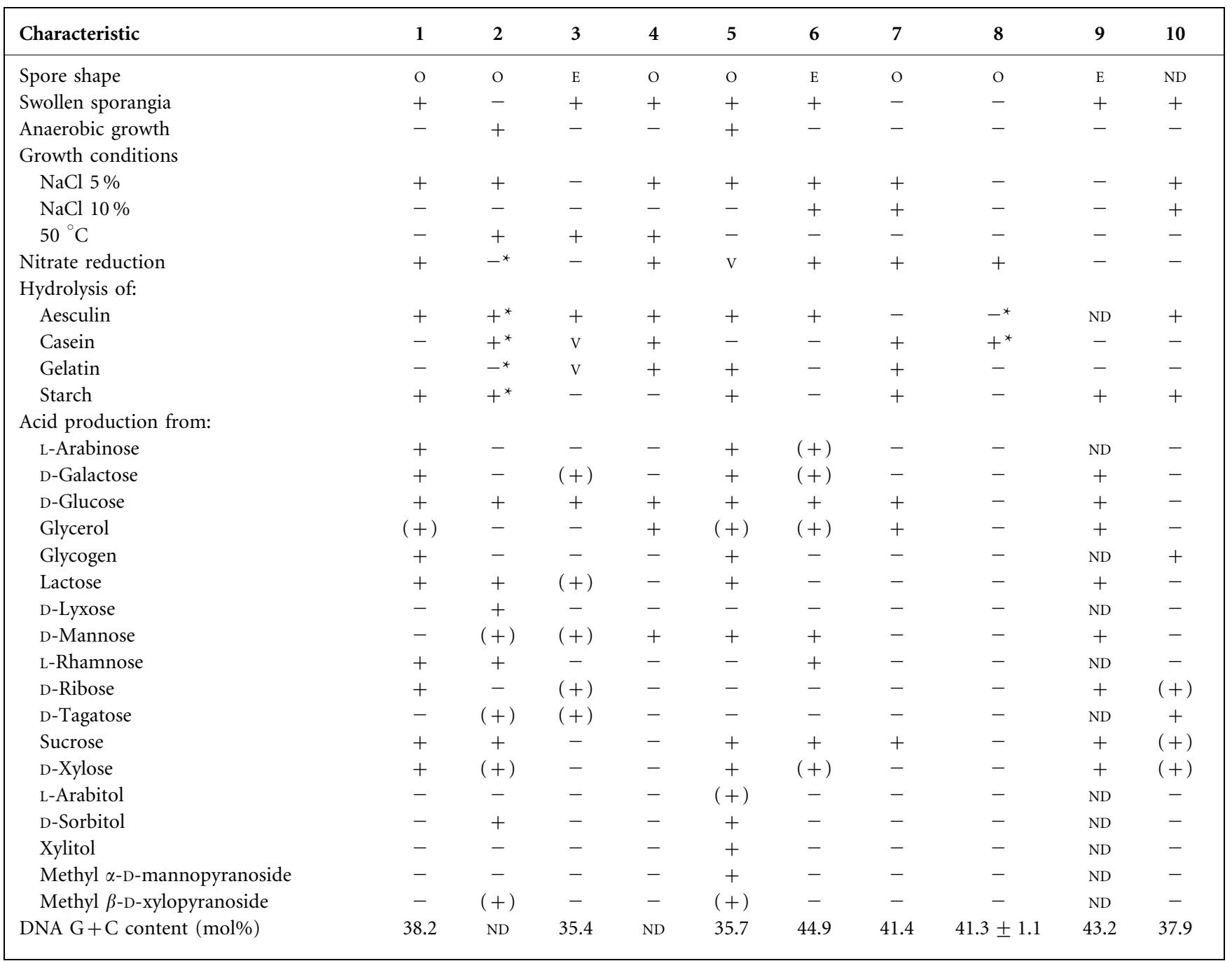

${ }^{*}$ Data from this study.

Nevertheless, strain ZLC- $26^{\mathrm{T}}$ formed a branch with $B$. siralis $171544^{\mathrm{T}}$ in these three phylogenetic trees. The DNA $\mathrm{G}+\mathrm{C}$ content of strain ZLC-26 ${ }^{\mathrm{T}}$ was $38.2 \mathrm{~mol} \%$, which differs slightly from its phylogenetically closest relatives (Table 1).

To differentiate strain ZLC- $26^{\mathrm{T}}$ from its closely related species, DNA-DNA hybridization was performed. Levels of DNA-DNA relatedness between strain ZLC-26 ${ }^{\mathrm{T}}$ and $B$. nealsonii DSM $15077^{\mathrm{T}}$, B. shackletonii DSM $18868^{\mathrm{T}}$, B. siralis DSM $13140^{\mathrm{T}}$ and $B$. circulans IAM $12462^{\mathrm{T}}$ were 21 , 11,17 and $35 \%$, respectively. These values indicate that strain ZLC- $26^{\mathrm{T}}$ represents a genomic species that is distinct from these four Bacillus species (Wayne et al., 1987).

The diagnostic diamino acid in the cell-wall peptidoglycan of strain ZLC- $26^{\mathrm{T}}$ was meso-diaminopimelic acid. The predominant isoprenoid quinone was MK-7. These characteristics are in agreement with those of numerous species of the genus Bacillus (Claus \& Berkeley, 1986). The major fatty acids of strain $\mathrm{ZLC}-26^{\mathrm{T}}$ were iso- $\mathrm{C}_{15: 0}$ $(35.2 \%), \mathrm{C}_{16: 1} \omega 11 c(16.1 \%)$ and anteiso- $\mathrm{C}_{15: 0}(15.6 \%)$. As shown in Table 2, some qualitative and quantitative differences in fatty acid contents could be observed 


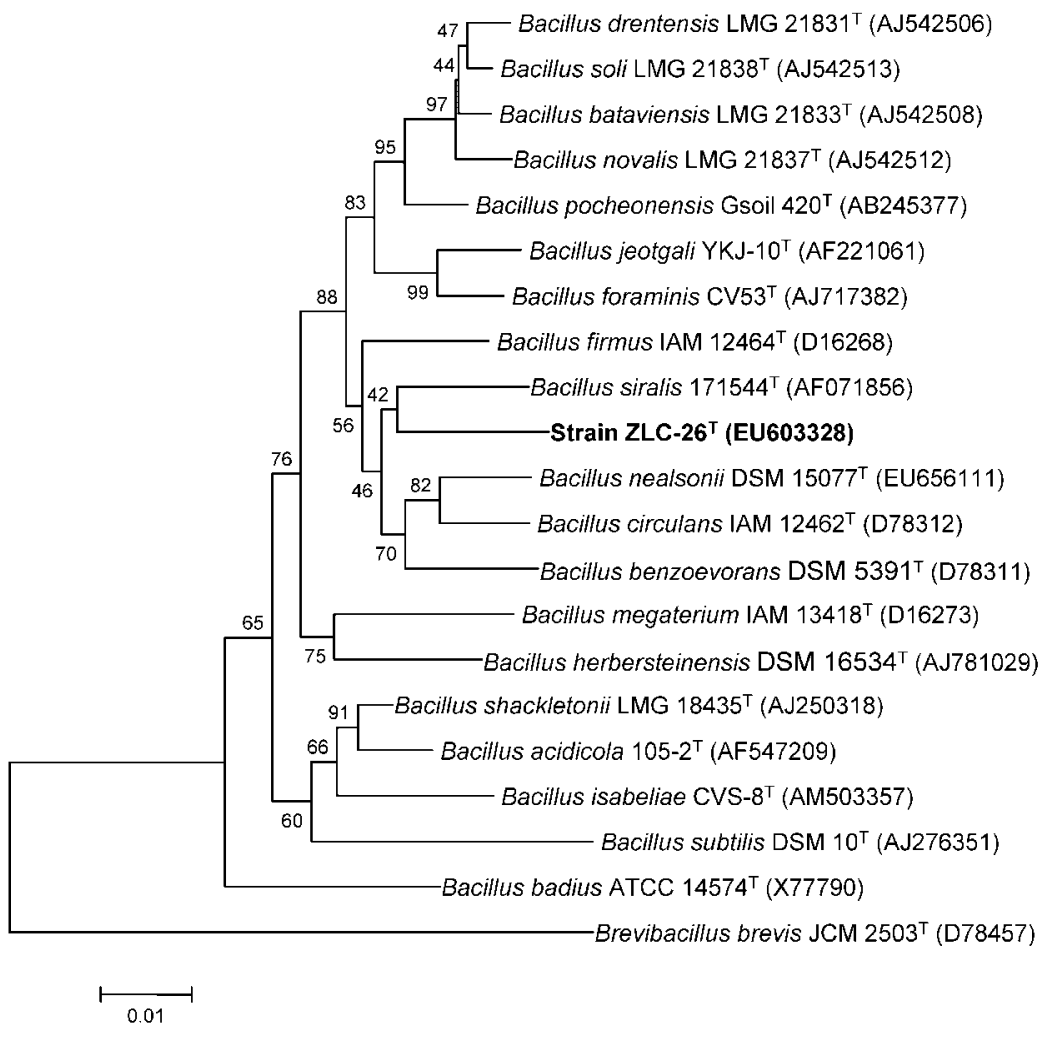

Fig. 1. Neighbour-joining phylogenetic tree based on 16S rRNA gene sequences showing the relationships of strain $\mathrm{ZLC}-26^{\top}$ and related taxa. Percentage bootstrap values based on 1000 replications are given at branch points. Brevibacillus brevis JCM 2503 ${ }^{\top}$ (D78457) was used as the outgroup. Bar, 0.01 substitutions per nucleotide position. between strain ZLC- $26^{\mathrm{T}}$ and its closely related species. In particular, in comparison with B. nealsonii DSM $15077^{\mathrm{T}}, B$. shackletonii DSM $18868^{\mathrm{T}}$, B. siralis DSM $13140^{\mathrm{T}}, B$. circulans IAM $12462^{\mathrm{T}}$ and $B$. firmus IAM $12464^{\mathrm{T}}$, strain ZLC- $26^{\mathrm{T}}$ contained larger amounts of $\mathrm{C}_{16: 1} \omega 11 \mathrm{c}$ and summed feature 3 . Additionally, strain ZLC- $26^{\mathrm{T}}$ could be differentiated from B. siralis DSM $13140^{\mathrm{T}}$ by the significantly smaller amount of iso- $\mathrm{C}_{17: 1} \omega 10 c$.

Therefore, on the basis of the data presented, strain ZLC$26^{\mathrm{T}}$ should be placed in the genus Bacillus as representing a novel species, for which the name Bacillus korlensis sp. nov. is proposed.

\section{Description of Bacillus korlensis sp. nov.}

Bacillus korlensis (kor.len'sis. N.L. masc. adj. korlensis pertaining to Korla, a city of Xinjiang Province in the north-west of China from where the type strain was isolated).

Cells are Gram-positive-staining, rod-shaped, strictly aerobic, spore-forming, $1.8-3.0 \mu \mathrm{m}$ long and $0.7-0.8 \mu \mathrm{m}$ wide. Cells are motile by means of peritrichous flagella. Endospores are oval, lie subterminally, occasionally paracentrally, and usually cause the sporangia to swell. Growth occurs at $7-45^{\circ} \mathrm{C}$; optimal temperature is $30-37{ }^{\circ} \mathrm{C}$. Growth occurs at $\mathrm{pH} 6.0-11.0$, with optimal growth at $\mathrm{pH}$ 7.0-8.0. Growth occurs at $0-8 \% \quad(\mathrm{w} / \mathrm{v}) \quad \mathrm{NaCl}$ (optimum, 0-2\%). Oxidase- and catalase-positive. Nitrate is reduced to nitrite. Hydrolyses aesculin and starch. Does not hydrolyse casein, gelatin, cellulose, chitin or tyrosine. $\mathrm{H}_{2} \mathrm{~S}$ production, citrate utilization, indole production and urease are negative. Acid is produced from glycerol (weakly), L-arabinose, D-ribose, D-xylose, Dgalactose, D-glucose, D-fructose, L-rhamnose, inositol, Dmannitol, methyl $\alpha$-D-glucopyranoside, $N$-acetylglucosamine, amygdalin, arbutin, aesculin, salicin, cellobiose, maltose, lactose, melibiose, sucrose, trehalose, inulin, melezitose, raffinose (weakly), starch, glycogen, gentiobiose, turanose and potassium gluconate (weakly), but not from erythritol, D-arabinose, L-xylose, D-adonitol, methyl $\beta$-D-xylopyranoside, D-mannose, L-sorbose, dulcitol, Dsorbitol, methyl $\alpha$-D-mannopyranoside, xylitol, D-lyxose, D-tagatose, D-fucose, L-fucose, D-arabitol, L-arabitol, potassium 2-ketogluconate or potassium 5-ketogluconate. According to the API ZYM gallery, produces alkaline phosphatase, esterase (C4), esterase lipase (C8), $\alpha$-chymotrypsin (weakly), acid phosphatase (weakly), naphthol-ASBI-phosphohydrolase, $\beta$-glucuronidase (weakly), $\alpha$-glucosidase and $\beta$-glucosidase, but not lipase (C14), leucine arylamidase, valine arylamidase, cystine arylamidase, tryp$\sin , \alpha$-galactosidase, $\beta$-galactosidase, $N$-acetyl- $\beta$-glucosaminidase, $\alpha$-mannosidase or $\alpha$-fucosidase. Susceptible to chloramphenicol, kanamycin, erythromycin, gentamicin, penicillin G, streptomycin, tetracycline and vancomycin. The cell-wall peptidoglycan contains meso-diaminopimelic acid. The predominant menaquinone is MK-7. Major fatty acids are iso- $\mathrm{C}_{15: 0}, \mathrm{C}_{16: 1} \omega 11 \mathrm{c}$ and anteiso- $\mathrm{C}_{15: 0}$. The DNA $\mathrm{G}+\mathrm{C}$ content of the type strain is $38.2 \mathrm{~mol} \%$. 
Table 2. Cellular fatty acid compositions (\%) of strain $\mathrm{ZLC}-26^{\top}$ and some related Bacillus species

Strains: 1, Bacillus korlensis sp. nov. ZLC-26 ${ }^{\mathrm{T}} ; 2$, B. nealsonii DSM $15077^{\mathrm{T}}$; 3, B. shackletonii DSM $18868^{\mathrm{T}}$; 4, B. siralis DSM $13140^{\mathrm{T}} ; 5$, B. circulans IAM $12462^{\mathrm{T}} ; 6$, B. firmus IAM $12464^{\mathrm{T}} ; 7$, B. pocheonensis DSM $18135^{\mathrm{T}} ; 8$, B. benzoevorans DSM $5391^{\mathrm{T}}$. All data from this study. Data for columns 1-6 were obtained after growth on TSA at $30{ }^{\circ} \mathrm{C}$ for $24 \mathrm{~h}$, for column 7 after growth on R2A agar at $30{ }^{\circ} \mathrm{C}$ for $24 \mathrm{~h}$ and for column 8 after growth on NA supplemented with $0.4 \%$ yeast extract and $0.2 \%$ benzoate at $30{ }^{\circ} \mathrm{C}$ for 24 h. - , Not detected.

\begin{tabular}{|c|c|c|c|c|c|c|c|c|}
\hline Fatty acid & 1 & 2 & 3 & 4 & 5 & 6 & 7 & 8 \\
\hline \multicolumn{9}{|c|}{ Straight-chain saturated } \\
\hline $\mathrm{C}_{14: 0}$ & 3.0 & 7.8 & 1.6 & 0.7 & 2.5 & 1.8 & 3.1 & 3.2 \\
\hline $\mathrm{C}_{15: 0}$ & - & - & - & 0.4 & - & - & 2.2 & 0.5 \\
\hline$C_{16: 0}$ & 4.7 & 3.5 & 0.4 & 0.8 & 2.3 & 1.4 & 3.6 & 17.6 \\
\hline $\mathrm{C}_{17: 0}$ & 0.1 & 0.1 & 0.1 & 0.1 & - & - & 0.3 & 0.3 \\
\hline $\mathrm{C}_{18: 0}$ & 0.4 & 0.2 & - & - & 0.1 & 0.6 & - & 0.8 \\
\hline \multicolumn{9}{|l|}{ Branched saturated } \\
\hline iso- $\mathrm{C}_{13: 0}$ & 0.4 & 2.3 & 0.1 & 0.1 & 0.5 & 0.2 & - & 0.3 \\
\hline iso- $\mathrm{C}_{14: 0}$ & 3.7 & 9.5 & 0.5 & 1.2 & 5.5 & 2.7 & 18.3 & 14.9 \\
\hline iso- $\mathrm{C}_{15: 0}$ & 35.2 & 15.6 & 41.3 & 57.4 & 21.7 & 37.1 & 13.8 & 7.9 \\
\hline iso- $\mathrm{C}_{16: 0}$ & 0.8 & 3.5 & 2.9 & 1.2 & 6.4 & 2.5 & 15.3 & 5.2 \\
\hline iso- $\mathrm{C}_{17: 0}$ & 3.7 & 0.2 & 0.4 & 3.2 & 1.0 & 1.9 & 0.6 & 0.4 \\
\hline anteiso- $\mathrm{C}_{15: 0}$ & 15.6 & 38.7 & 23.7 & 10.4 & 47.3 & 16.8 & 28.1 & 28.4 \\
\hline anteiso- $\mathrm{C}_{17: 0}$ & 1.8 & 2.3 & 13.2 & 2.1 & 6.6 & 3.6 & 1.8 & 1.7 \\
\hline iso- $\mathrm{C}_{13: 0} 3-\mathrm{OH}$ & 0.4 & 1.2 & 0.6 & 0.2 & 0.2 & 0.9 & 1.4 & 0.6 \\
\hline \multicolumn{9}{|l|}{ Mono-unsaturated } \\
\hline $\mathrm{C}_{16: 1} \omega 11 c$ & 16.1 & 5.2 & 1.8 & 2.2 & 1.2 & 3.1 & 1.1 & 7.4 \\
\hline $\mathrm{C}_{16: 1} \omega 7 c$ alcohol & 3.2 & 1.5 & 0.5 & 3.1 & 1.7 & 5.3 & 1.8 & 0.7 \\
\hline iso- $\mathrm{C}_{17: 1} \omega 10 c$ & 1.5 & - & 1.1 & 8.2 & 0.4 & 2.4 & - & - \\
\hline \multicolumn{9}{|l|}{ Summed features* } \\
\hline 3 & 4.1 & 0.3 & 0.1 & - & - & 0.4 & - & - \\
\hline 4 & 1.4 & 0.2 & 3.3 & 2.1 & 0.6 & 11.4 & - & - \\
\hline
\end{tabular}

* Summed features represent groups of two or three fatty acids that could not be separated by gas liquid chromatography with the MIDI system. Summed feature 3 contained $\mathrm{C}_{16: 1} \omega 7 c$ and/or iso- $\mathrm{C}_{15: 0} 2-\mathrm{OH}$; summed feature 4 contained anteiso- $\mathrm{C}_{17: 1}$ $\mathrm{B}$ and/or iso- $\mathrm{C}_{17: 1} \mathrm{I}$.

The type strain, ZLC- $26^{\mathrm{T}}$ (=CCTCC AB $207172^{\mathrm{T}}=\mathrm{NRRL}$ B-51302 ${ }^{\mathrm{T}}$ ), was isolated from a sand soil sample collected from Korla, Xinjiang Province, China.

\section{Acknowledgements}

This work was supported by the R \& D Infrastructure and Facility Development Program from the Ministry of Science and Technology of the People's Republic of China (Grant no. 2005DKA21208).

\section{References}

Aino, K., Hirota, K., Matsuno, T., Morita, N., Nodasaka, Y., Fujiwara, T., Matsuyama, H., Yoshimune, K. \& Yumoto, I. (2008). Bacillus polygoni sp. nov., a moderately halophilic, non-motile obligate alkaliphile isolated from indigo balls. Int J Syst Evol Microbiol 58, 120-124

Albert, R. A., Archambault, J., Rosselló-Mora, R., Tindall, B. J. \& Matheny, M. (2005). Bacillus acidicola sp. nov., a novel mesophilic, acidophilic species isolated from acidic Sphagnum peat bogs in Wisconsin. Int J Syst Evol Microbiol 55, 2125-2130.
Albuquerque, L., Tiago, I., Taborda, M., Nobre, M. F., Veríssimo, A. \& da Costa, M. S. (2008). Bacillus isabeliae sp. nov., a halophilic bacterium isolated from a sea salt evaporation pond. Int J Syst Evol Microbiol 58, 226-230.

Buczolits, S., Denner, E. B. M., Vybiral, D., Wieser, M., Kämpfer, P. \& Busse, H.-J. (2002). Classification of three airborne bacteria and proposal of Hymenobacter aerophilus sp. nov. Int J Syst Evol Microbiol 52, 445-456.

Chun, J., Lee, J.-H., Jung, Y., Kim, M., Kim, S., Kim, B. K. \& Lim, Y. W. (2007). EzTaxon: a web-based tool for the identification of prokaryotes based on $16 \mathrm{~S}$ ribosomal RNA gene sequences. Int J Syst Evol Microbiol 57, 2259-2261.

Claus, D. \& Berkeley, R. C. W. (1986). Genus Bacillus Cohn 1872. In Bergey's Manual of Systematic Bacteriology, vol. 2, pp. 1105-1140. Edited by P. H. A. Sneath, N. S. Mair, M. E. Sharpe \& J. G. Holt. Baltimore: Williams \& Wilkins.

Doetsch, R. N. (1981). Determinative methods of light microscopy. In Manual of Methods for General Bacteriology, pp. 21-33. Edited by P. Gerhardt, R. G. E. Murray, R. N. Costilow, E. W. Nester, W. A. Wood, N. R. Krieg \& G. H. Phillips. Washington, DC: American Society for Microbiology.

Euzéby, J. P. (2008). List of Prokaryotic Names with Standing in Nomenclature. http://www.bacterio.cict.fr/ 
Ezaki, T., Hashimoto, Y. \& Yabuuchi, E. (1989). Fluorometric deoxyribonucleic acid-deoxyribonucleic acid hybridization in microdilution wells as an alternative to membrane filter hybridization in which radioisotopes are used to determine genetic relatedness among bacterial strains. Int J Syst Bacteriol 39, 224-229.

Felsenstein, J. (2006). PHYLIP (phylogeny inference package), v3.66. Distributed by the author. Department of Genome Sciences, University of Washington, Seattle, USA.

Kovács, N. (1956). Identification of Pseudomonas pyocyanea by the oxidase reaction. Nature 178, 703-704.

Kuisiene, N., Raugalas, J., Spröer, C., Kroppenstedt, R. M. \& Chitavichius, D. (2008). Bacillus butanolivorans sp. nov., a species with industrial application for the remediation of n-butanol. Int J Syst Evol Microbiol 58, 505-509.

Kumar, S., Tamura, K. \& Nei, M. (2004). MEGA3: integrated software for molecular evolutionary genetics analysis and sequence alignment. Brief Bioinform 5, 150-163.

Lane, D. J. (1991). 16S/23S rRNA sequencing. In Nucleic Acid Techniques in Bacterial Systematics, pp. 115-175. Edited by E. Stackebrandt \& M. Goodfellow. Chichester: Wiley.

Lin, Y.-C., Uemori, K., de Briel, D. A., Arunpairojana, V. \& Yokota, A. (2004). Zimmermannella helvola gen. nov., sp. nov., Zimmermannella alba sp. nov., Zimmermannella bifida sp. nov., Zimmermannella faecalis sp. nov. and Leucobacter albus sp. nov., novel members of the family Microbacteriaceae. Int J Syst Evol Microbiol 54, 1669-1676.

Logan, N. A., Lebbe, L., Verhelst, A., Goris, J., Forsyth, G., RodriguezDiaz, M., Heyndrickx, M. \& De Vos, P. (2004). Bacillus shackletonii sp. nov., from volcanic soil on Candlemas Island, South Sandwich archipelago. Int J Syst Evol Microbiol 54, 373-376.

Mesbah, M., Premachandran, U. \& Whitman, W. B. (1989). Precise measurement of the $\mathrm{G}+\mathrm{C}$ content of deoxyribonucleic acid by highperformance liquid chromatography. Int J Syst Bacteriol 39, 159-167.

MIDI (1999). Sherlock Microbial Identification System Operating Manual, version 3.0. Newark, DE: MIDI, Inc.

Pettersson, B., de Silva, S., Uhlèn, M. \& Priest, F. G. (2000). Bacillus siralis sp. nov., a novel species from silage with a higher order structural attribute in the 16S rRNA genes. Int J Syst Evol Microbiol 50, 2181-2187.
Pichinoty, F., Asselineau, J. \& Mandel, M. (1984). Charactérisation biochemique de Bacillus benzoevorans sp. nov., une nouvelle espèce filamenteuse, engainée et mésophile dégradant divers acides aromatiques et phénols. Ann Microbiol (Paris) 135B, 209-217 (in French).

Rhodes, M. E. (1958). The cytology of Pseudomonas spp. as revealed by a silver-plating staining method. J Gen Microbiol 18, 639-648.

Smibert, R. M. \& Krieg, N. R. (1994). Phenotypic characterization. In Methods for General and Molecular Bacteriology, pp. 607-654. Edited by P. Gerhardt, R. G. E. Murray, W. A. Wood \& N. R. Krieg. Washington, DC: American Society for Microbiology.

Staneck, J. L. \& Roberts, G. D. (1974). Simplified approach to identification of aerobic actinomycetes by thin-layer chromatography. Appl Microbiol 28, 226-231.

Ten, L. N., Baek, S.-H., Im, W.-T., Larina, L. L., Lee, J.-S., Oh, H.-M. \& Lee, S.-T. (2007). Bacillus pocheonensis sp. nov., a moderately halotolerant, aerobic bacterium isolated from soil of a ginseng field. Int J Syst Evol Microbiol 57, 2532-2537.

Thompson, J. D., Gibson, T. J., Plewniak, F., Jeanmougin, F. \& Higgins, D. G. (1997). The CLUSTAL_X windows interface: flexible strategies for multiple sequence alignment aided by quality analysis tools. Nucleic Acids Res 25, 4876-4882.

Venkateswaran, K., Kempf, M., Chen, F., Satomi, M., Nicholson, W. \& Kern, R. (2003). Bacillus nealsonii sp. nov., isolated from a spacecraftassembly facility, whose spores are gamma-radiation resistant. Int $J$ Syst Evol Microbiol 53, 165-172.

Wayne, L. G., Brenner, D. J., Colwell, R. R., Grimont, P. A. D., Kandler, O., Krichevsky, M. I., Moore, L. H., Moore, W. E. C., Murray, R. G. E. \& other authors (1987). International Committee on Systematic Bacteriology. Report of the ad hoc committee on reconciliation of approaches to bacterial systematics. Int $J$ Syst Bacteriol 37, 463-464.

Wilson, K. (1987). Preparation of genomic DNA from bacteria. In Current Protocols in Molecular Biology, pp. 2.4.1-2.4.5. Edited by F. M. Ausubel, R. Brent, R. E. Kingston, D. D. Moore, J. G. Seidman, J. A. Smith \& K. Struhl. New York: Green Publishing \& Wiley-Interscience.

Xie, C. H. \& Yokota, A. (2003). Phylogenetic analysis of Lampropedia hyalina based on the 16S rRNA gene sequence. J Gen Appl Microbiol 49, 345-349. 